\title{
Pediatric Hand Blast Injury Profile in Emergency Room of Dr. Hasan Sadikin General Hospital Bandung
}

\author{
Yoyos Dias Ismiarto, Yoan Putrasos Arif \\ Department of Orthopaedics and Traumatology Faculty of Medicine Universitas Padjadjaran \\ Dr. Hasan Sadikin General Hospital Bandung, Indonesia
}

\begin{abstract}
In the past, blast injuries were mainly caused by war-related incidents. However, despite the current lack of warrelated activities, blast injuries are still seen due to unintentional low explosive material blasts which are mostly seen on children's hand. However, the classification for the severity of this type of injury is still unclear. The aim of this study was to assess the incident, patterns, and severity of hand blast injuries among pediatric patients treated in Dr. Hasan Sadikin General Hospital. Twenty two pediatric patients in Dr. Hasan Sadikin General Hospital Bandung from 2013-2017 were included in this study. All data were extracted retrospectively from patient medical records and the degree of injury severity was assessed using Hand Injury Severity Score (HISS). There were 22 hand injuries caused by explosion identified in 18 boys with the age range of 5 to 15 years. Hand injuries from explosions have a specific pattern with the hand radial side experiencing the most severe damage including the thumb (16 cases), index finger (16 cases), and middle finger (14 cases). The severity of the injuries varied from mild ( 3 cases) to moderate (4 cases), severe ( 7 cases), and major (8 cases). A high incidence of major hand blast injuries is found among pediatric patients with the hand radial side tends to suffer the most severe damage.
\end{abstract}

Key words: Blast injury, injury pattern, pediatric hand, severity of injury

\section{Profil Cedera Tangan Akibat Ledakan pada Anak di Ruangan Gawat Darurat RSUP Dr. Hasan Sadikin Bandung}

Abstrak

Cedera akibat ledakan di masa lalu terutama disebabkan oleh situasi peperangan. Saat ini cedera akibat ledakan masih terjadi terutama pada tangan anak yang disebabkan oleh ledakan bahan berdaya rendah yang tidak disengaja. Namun, klasifikasi untuk menentukan derajat keparahan cedera masih belum jelas. Tujuan dari penelitian ini adalah menganalisis insidensi, pola, dan derajat keparahan cedera terhadap pasien yang dirawat di Rumah Sakit Hasan Sadikin. Penelitian ini melibatkan 22 pasien anak di Rumah Sakit Dr. Hasan Sadikin Bandung periode 2013-2017. Semua data didapatkan secara retrospektif dari rekam medis pasien. Tingkat keparahan cedera dinilai menggunakan Hand Severity Severity Score (HISS). Dua puluh dua cedera tangan akibat ledakan teridentifikasi. Kelompok ini sebagian besar terdiri atas 18 anak laki-laki dengan rentang usia 5 hingga 15 tahun. Cedera tangan akibat ledakan memiliki pola tertentu, dengan sisi radial tangan mengalami kerusakan paling parah di antaranya 15 kasus mengenai ibu jari, 16 kasus mengenai jari telunjuk, dan 14 kasus mengenai jari tengah. Tingkat keparahan cedera bervariasi dari kasus ringan sebanyak 3 kasus, sedang sebanyak 4 kasus, berat sebanyak 7 kasus, dan parah sebanyak 8 kasus. Cedera ledakan di tangan anak memiliki angka kejadian yang tinggi dalam kategori berat dengan sisi radial tangan cenderung menderita kerusakan paling parah.

Kata kunci: Cedera akibat ledakan, derajat cedera, pola cedera, tangan anak

Corresponding Author: Yoan Putrasos Arif, Department of Orthopaedics and Traumatology Faculty of Medicine Universitas Padjadjaran/Dr. Hasan Sadikin General Hospital Bandung, Jl. Pasteur No. 38 Bandung, West Java, 40161 Indonesia, Email: yoan14001@mail.unpad.ac.id 


\section{Introduction}

In the past, blast injuries were mainly caused by injuries during wars among both soldiers and civilians. ${ }^{1}$ Nowadays, blast injuries still occur, mostly caused by low explosion such as firecrackers, with hands as the most frequently affected body part. ${ }^{2}$ The incidence of the injury is seasonal, with a peak during holiday seasons and cultural events, such as during Eid AlFitr, Christmas, New Year, or during wedding ceremonies. $^{3}$

Fireworks and firecrackers are often used during festivities due to their spectacular display of colors and loud sounds, reflecting the festive atmosphere in these events. ${ }^{1}$ They are frequently used globally in many kinds of festival, such asTihar in Nepal, Hari Raya in Malaysia and Indonesia, Ashura Day in Morocco, Guy Fawkes Night (Bonfire Night) in United Kingdom, Independence Day and Halloween in United States, Bastille Day in France, Fallas Day in Spain, New Year's Eve in Guatemala, Chinese New Year in China. ${ }^{1,2}$ Blast injuries from fireworks mainly affect children, with reported incidence of $7 / 100,000$ children annually, in which $70 \%$ of them are between 10-14 years old. ${ }^{4,5}$

Explosives are categorized into high explosives and low explosives according to their detonation velocity. Fireworks and firecrackers, as the most frequent causes of blast injuries, are categorized as low explosives. The severity of blast injuries is affected by the range of the explosives and size of the explosives. Various types of injuries may occur, such as laceration, avulsion, amputation, burn injuries, vascular injuries, compartment syndrome, fractures, and physeal plate injuries. ${ }^{6}$

Isolated blast injuries on the hands presented a certain pattern such as thumb hyperextension, thumb hyperabduction, laceration at first interdigital space, traumatic amputation at distal fingers, and many others. The etiology of such patterns includes tears of volar plate, disinsertion of intrinsic muscles, tendon rupture, and accompanying neurovascular deficiencies. ${ }^{7,8}$ Debates on classification of injury severity are still ongoing despite the wide use of Hand Injury Severity Score for predicting functional outcome after healing due to its good accuracy., ${ }^{8,9}$ The management of this injury requires extensive understanding of children's anatomical structure, pathomechanism, and several hand reconstructive techniques. ${ }^{8,10}$

This study aimed at toevaluate the most common blast injury patterns as well as their pathomechanism, severity, and management in pediatric patients.

\section{Methods}

The study was conducted retrospectively using the medical records of patients admitted to the Emergency Department of Dr. Hasan Sadikin General Hospital, Bandung, during the period of January 2013 to December 2017. Available medical records, clinical photographs, radiographic finding, and surgical reports were collected to understand patient demographics.

There were 30 patients presented with hand blast injuries during the period studied. Inclusion criteria of the study were hand blast injuries that required surgical interventions. Eight cases were excluded from this study due to the age of the patients ( $>15$ years old). Brief history taking was performed through analysis of medical records. The severity of hand injury was categorized into mild, moderate, and severe according to HISS based on clinical photographs, radiographic findings, and surgical reports. ${ }^{15}$ Most of the patients received wound debridement, internal fixation, and soft tissue repair followed with primary sutures.

Patients with mild injuries only experienced soft tissue wounds without accompanying bone or joint damage thus allowing for earlier mobilization after wound repair and better prognosis. Moderate injuries were described as soft tissue, bone, and/or joint damage without amputation with any degree of residual stiffness of the hands. Severe injuries were described as wounds accompanied with partial or full amputation of the hand that may require amputation surgery and caused disability.

\section{Results}

Twenty five cases of pediatric blast injury of the hand were found during the period of the study, with the youngest patient aged 5 years old. These cases involved 18 boys and 7 girls with the age range of 5-15 years. From the history taking, it was revealed that the injuries were caused by low explosive materials such as fireworks and firecrackers. Blast injuries at the hand may be categorized as seasonal injury which peaks during religious festivities and New Year Eves and rarely seen during the regular period. In this study, the pediatric patients with blast injuries at the hand were admitted during Eid Al-Fitr, New 
Table Hand Injury Severity Score ${ }^{15}$

\begin{tabular}{|c|c|c|}
\hline \multicolumn{2}{|l|}{ Variables } & \\
\hline \multicolumn{3}{|l|}{ Motor } \\
\hline \multicolumn{3}{|l|}{ Absolute } \\
\hline Wrist flexor or extensor (each) & & 10 \\
\hline \multicolumn{3}{|l|}{ Weighted (See 'Weighting Factors) } \\
\hline \multirow[t]{2}{*}{ Extensor tendon } & Proximal to PIPJ & 1 \\
\hline & Distal to PIPJ & 3 \\
\hline \multirow[t]{4}{*}{ Flexor profundus (incl. FPL) } & Zone 1 & 6 \\
\hline & Zone 2 & 6 \\
\hline & Zone 3 & 5 \\
\hline & Zone 4, 5, belly & 3 \\
\hline \multirow[t]{2}{*}{ Flexor Superfiscialis } & Distal to wrist & 5 \\
\hline & Proximal to wrist & 2 \\
\hline Crush or avulsion of above & DOUBLE the Score & \\
\hline \multicolumn{3}{|l|}{ Neurovascular } \\
\hline \multicolumn{3}{|l|}{ Absolute } \\
\hline \multirow[t]{4}{*}{ Nerve } & Main median $\mathrm{n}$. & 60 \\
\hline & Main ulnar n. & 60 \\
\hline & Motor branch of ulnar $n$. & 30 \\
\hline & Deep branch of ulnar $n$. & 30 \\
\hline \multirow[t]{2}{*}{ Artery } & Radial artery & 10 \\
\hline & Ulnar artery & 10 \\
\hline \multicolumn{3}{|l|}{ Weighted (See 'Weighting Factors') } \\
\hline \multirow[t]{2}{*}{ Digital nerve } & One & 3 \\
\hline & Both & 4 \\
\hline \multirow[t]{2}{*}{ Digital artery } & One & 3 \\
\hline & Both & 6 \\
\hline Crush or avulsion of neurovascular bundle & DOUBLE the score & \\
\hline \multicolumn{3}{|l|}{ Weighting Factors } \\
\hline \multicolumn{3}{|l|}{ The following apply to weighted scores } \\
\hline & Thumb $\times 6$ & Ringx3 \\
\hline & Index $\quad x 2$ & Littlex2 \\
\hline & Middle $\times 3$ & Hand \& Forearm x 1 \\
\hline
\end{tabular}

Year Eve, and Chinese New Year (Figure 1).

The injury predominantly occurred in the radial part when compared to the ulnar part. Index finger was the most commonly affected finger in blast injuries. The distribution of laceration in palms and digits shown in the majority of injuries occur in the radial digits and center of the palm. Significant tissue damage occurred in first interdigital web space and center of the palm. The majority of amputations affected the metacarpophalangeal and interphalangeal joints. Metacarpal bone fractures, physeal plate injuries, and carpometacarpal disarticulation were also found in several cases of hand blast injuries (Figure 2).

The most commonly identified mechanism of injury was holding or throwing low explosive with the dominant hand. The most frequent 


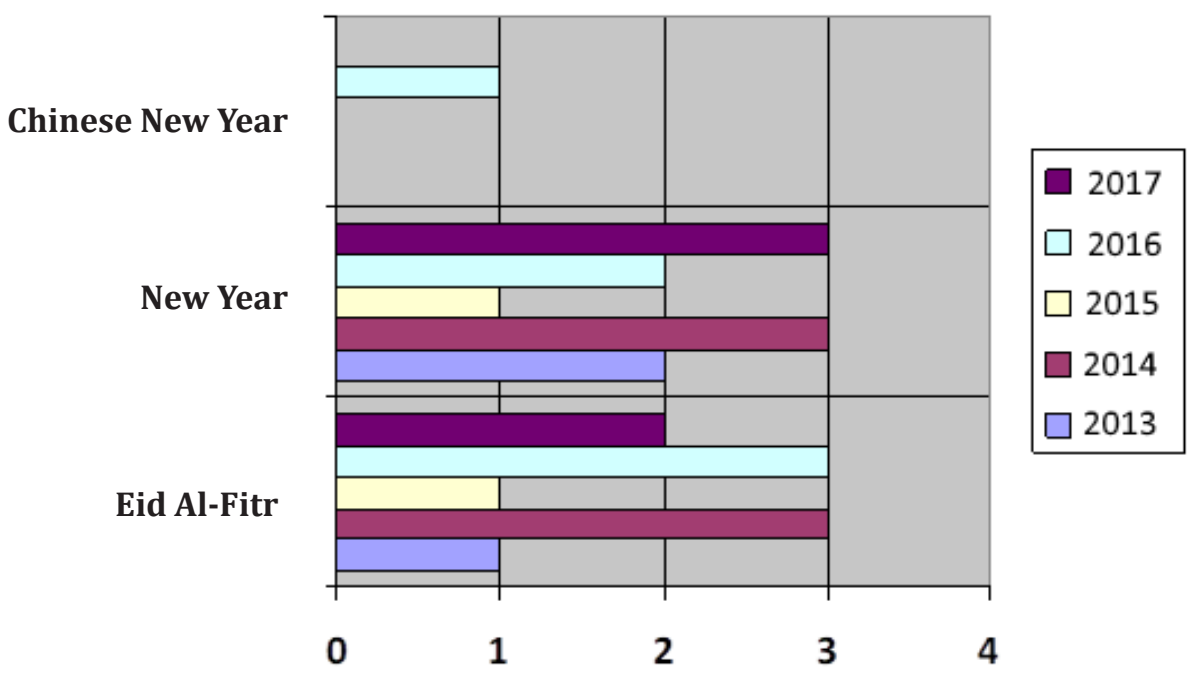

Figure 1 Distribution of Blast Injuries at the Hand According to Annual Events

presentation of the injury was hyperextension or hyperabduction of thumbs and other fingers. Joint hyperextension was correlated with soft tissue avulsion, amputation, or finger disarticulation at the radial part of the fingers. The degree of hyperabduction of first interdigital web space was correlated with the degree of laceration and damage of the palmar soft tissues (Figure 3).

Figure 4 describes the types of injuries according to the fingers. Thumb, index finger, and middle finger were fingers that were most frequently involved in trauma that caused soft tissue injury, with 8 cases happened to the thumbs, 7 cases to the index finger, and 4 cases to the middle finger. Soft tissue injuries directly affect the range of motion (ROM) during active flection after the skin folds above interphalangeal joints have healed and converted into scar tissue. ${ }^{1}$ The scar tissue may adversely affect the ability to grab objects and may also affect other functions of the hand.

Fractures may occur at the thumb (8 cases), index finger ( 7 cases), or middle fingers ( 4 cases). The highest incidence of traumatic amputation was for index finger (6 cases) and thumbs (4 cases). Other injuries were found at the interdigital web space and palms in 2 cases. Ring finger and little finger injuries predominantly involved soft tissue injuries with 7 cases and 1 case, respectively, and with lower incidence when compared to the injuries occurring at thumbs, index finger, and middle finger (Figure 4). Tendon injuries ( 2 cases) and neurovascular
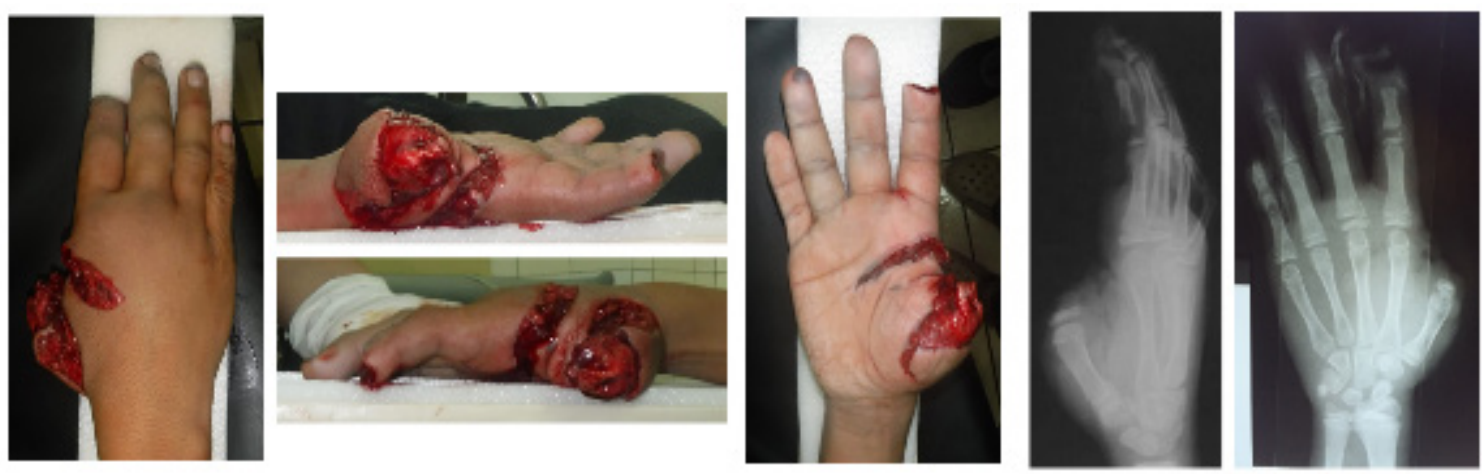

Figure 2 Severe Blast Injury of the Hand in a 12-years Old Boy (HISS=130) 

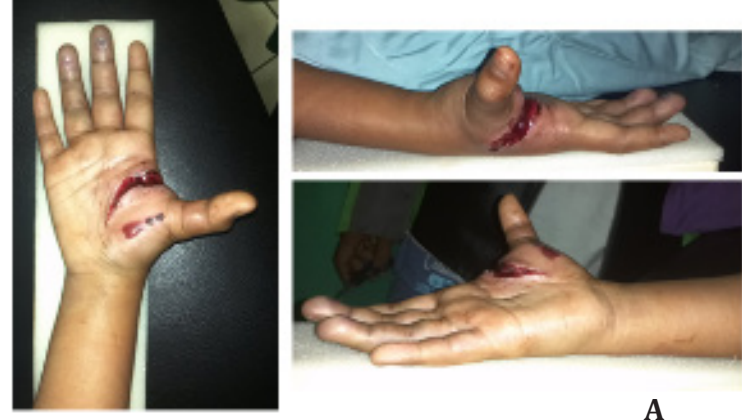

A
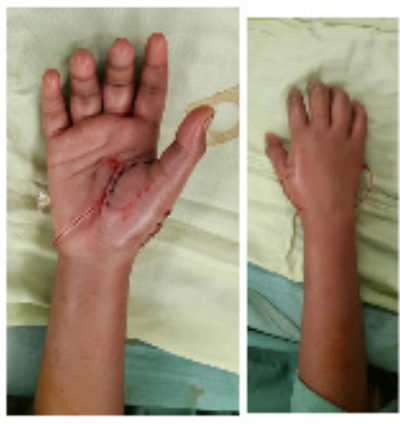

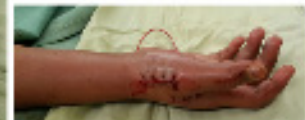

C
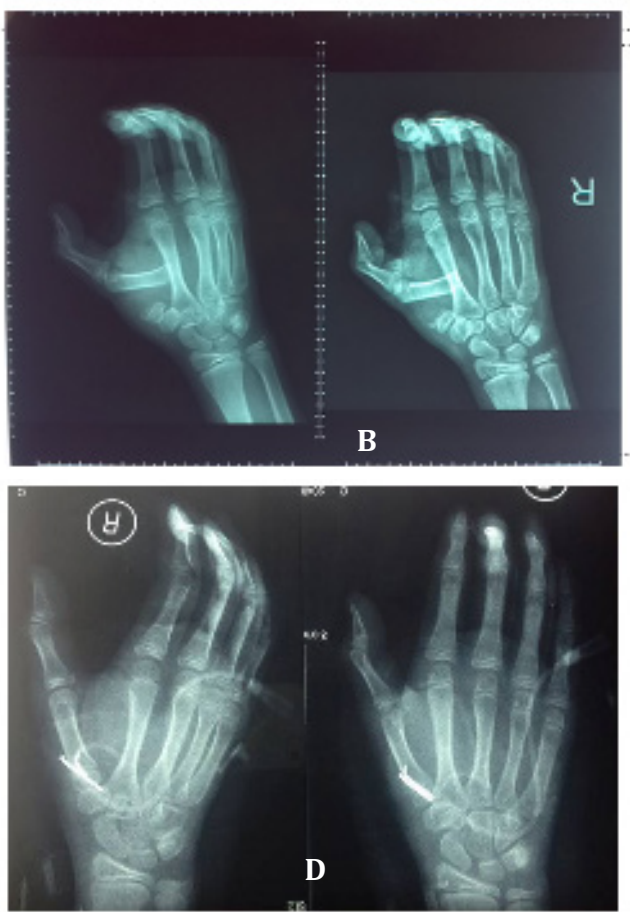

Figure 3 Clinical Picture of Interdigital Web Space Hyperextension

(A) with documented physeal plate injury of first metacarpal base from plain radiographs (B) in 8-years old girl. (C) and (D) results after wound debridement, muscle repair, ORIF K-Wire, and primary suture.

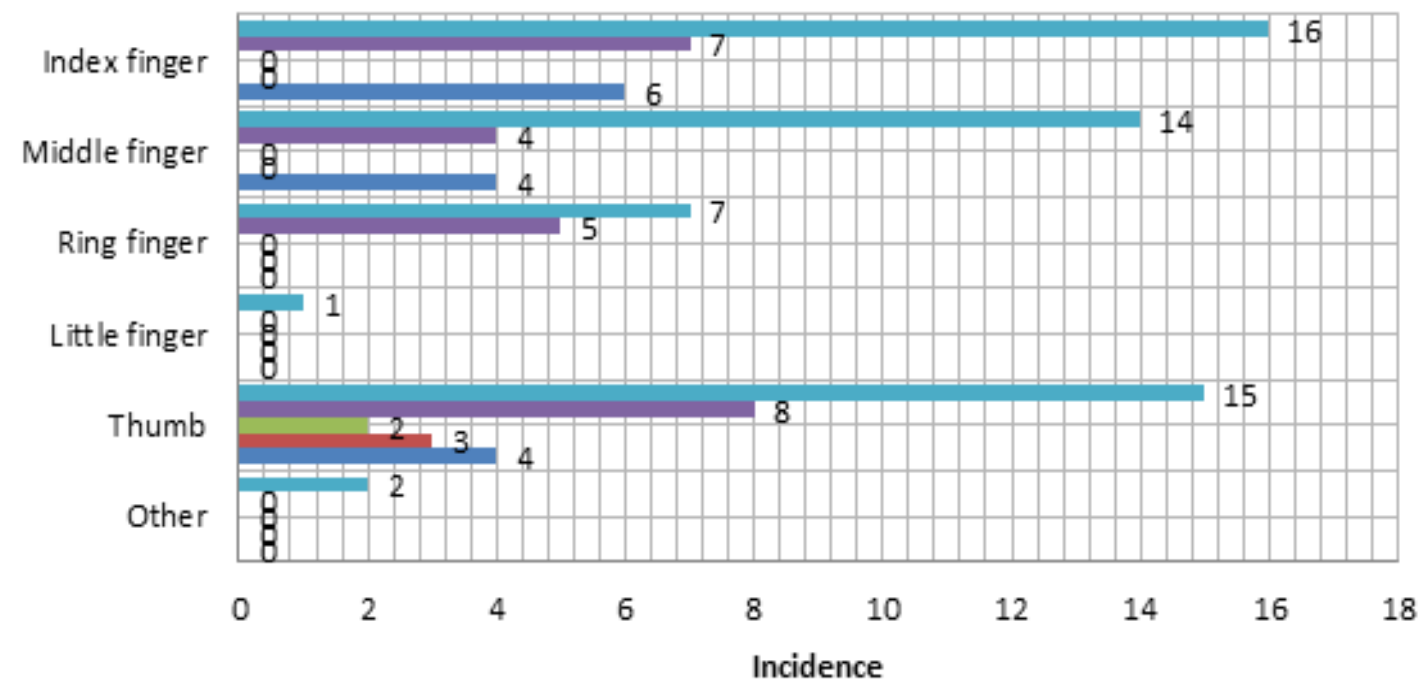

\footnotetext{
Soft tissue injury $\quad$ Fracture Tendon injury

neurovascular injury $\quad$ Traumatic amputation
}

Figure 4 Types of Injuriy based on Each Fingers $(n=22)$ 


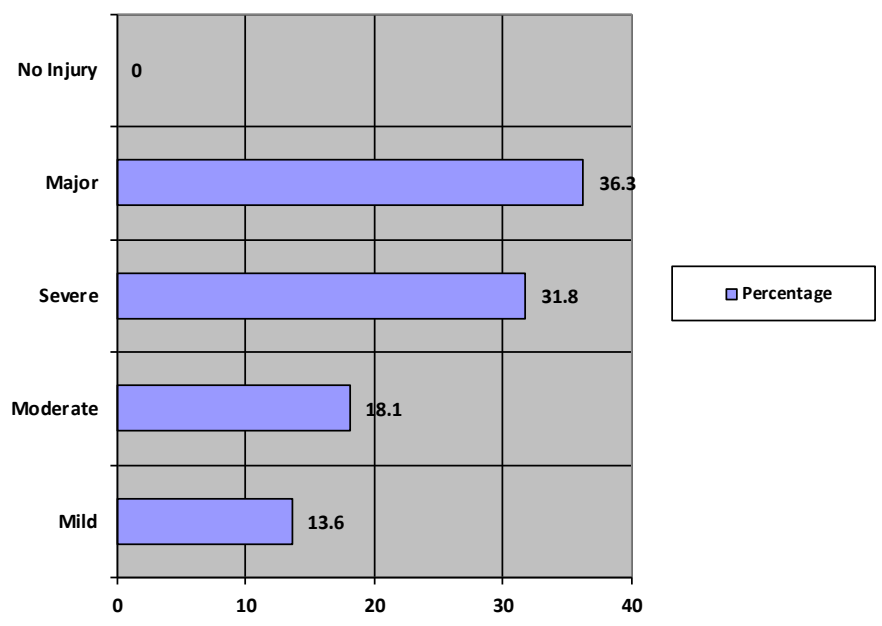

Figure 5 HISS of Children with Blast Injuries of the Hand $(n=22)$

injuries ( 3 cases) were found only in the thumbs. Hand injuries were classified using the Hand Injury Severity Score (HISS). ${ }^{15,16}$ This scoring system evaluates four organs of the hand: skin, bones, muscles, and neurovascular components and is widely used due to its descriptive evaluation of severity in injuries distal to carpal bones. This classification system does not discriminate between different mechanisms of hand injuries.

The HISS scoring have four degrees of severity and correlates with the functional outcomes of the hands. ${ }^{15,16}$ These degrees of severity are mild $(<20)$, moderate $(21-50)$, severe $(50-100)$, and major $(>100)$. Mild injuries include injuries that only involve soft tissue without bone or joint involvement while moderate injuries involve soft tissue injuries with bone and/ or joint involvement. Severe injuries involve neurovascular damages in addition to the moderate injuries and major injuries involve partial or full amputation of the hand. Low HISS score indicates milder injuries and correlates with good prognosis and good post-recovery functional outcome. ${ }^{16}$

The HISS score is specific for each wound with each digit evaluated separately for its components (skin, bones, motoric components, and neurovascular components). The HISS score is the sum of all digital components and its weighting factors. The severity of the injuries in this study, as assessed using HISS scoring system, is presented in Figure 5 with $13.6 \%$ of all cases were mild cases, $18.1 \%$ were moderate cases, $31.8 \%$ were severe cases, and $36.3 \%$ were severe cases.

All blast injuries in this study were managed surgically, with wound debridement, open reduction, internal fixation of the bones, and soft tissue repair followed with primary suture. No index finger pollicization and microsurgical procedures were performed in any of the cases.

\section{Discussion}

In this study, the age range was 515 years with boys comprised the majority of the patients, i.e. $82 \%$. In several other reports, the incidence rate of fireworks and firecracker-related injuries in children aged under 15 years old ranges between 40 and $50 \%{ }^{8,13}$ United States, as a liberal country, has allowed the use of fireworks or firecrackers with 7 times higher use of low explosives compared to other countries with stricter rules of fireworks and firecracker use. . $^{6,10}$ The most common blast injury in this study was laceration of first interdigital web space with varying degrees of thenar muscle injuries, dislocation of dorsal carpometacarpal joint, dislocation of the thumb, and injuries of $2^{\text {nd }}-3^{\text {rd }}$ metacarpals. In this study, many patients have suffered from partial amputation of thumb, and $2^{\text {nd }}$ and $3^{\text {rd }}$ digit of the hands. The pathomechanism of blast injury of the hand is as follows: hand is comprised of 4 components, with thumbs being the most mobile finger compared to the others due to the saddle joint articulating with CMC. 
Index fingers is the second most mobile finger, fixated on the center of metacarpals. The rest of the fingers are more firmly fixated on the metacarpals, although each fingers still have a mechanical function when grasping objects. ${ }^{12}$

To grasp an object, such as fireworks or firecrackers, thumb and index finger emulates with other fingers as supporting structures and stabilizes the grip. ${ }^{12}$ When the explosive is triggered when it is still held or in near proximity of the hand, several vectors acting centrifugally may cause injuries to the hand. The vector of the blast may cause tears of the first interdigital web space. ${ }^{12}$ The spread of vectors will then damage saddle joint of the thumb, thus causing dorsal dislocation.

The centrifugal vectors will afterwards continue to damage other fingers and the center of the palm. The MCP joints of other fingers resist the vector, of which damages may occur if the vector exceeded the resistance of the joints, causing tears starting from volar plate and increasing the degree of hyperextension. ${ }^{12}$ Interphalangeal joints are more firmly fixated at the volar plates; thus there is a higher probability that amputation occurs in this area. The center of the palm consists of $2^{\text {nd }}$ and $3^{\text {rd }}$ metacarpals that are firmly attached to carpal bones of the hand with the axis located on the weakest point of the structure. The blast vector then may cause fracture or physeal plate of the palm. ${ }^{16}$

This study has a limitation in terms of the classification using HISS in pediatric patients may not be fully accepted due to the lack of consensus on whether physeal plate injury has a stronger correlation with the functional outcome when compared to fractures of the hand. Multicenter studies need to be performed in order to acquire higher data quality regarding hand blast injuries in children.

Pediatric hand blast injuries have a high incidence rate in the major category with the hand radial side tends to suffer the most severe damage. The blast injuries found in the study include lacerations, muscle tears, tendon rupture, fractures or physeal plate injuries, and traumatic amputation. The main mechanism of blast injury in this study was unintentional detonation of low explosive materials while being held by the hand

The high incidence of hand blast injuries in children may require the implementation of government policies and regulation regarding the use of low explosives material. Because this injuries are seasonal in nature, with higher incidences during festivities, it is necessary to increase caution during such occasions. Parents are fully responsible to educate their children on the dangers of low explosive materials and to monitor the use of low explosive materials by their children.

\section{References}

1. Rajeswari B, Shankari B, Selvaraj A. Epidemiology of cracker (fireworks) injuries in a tertiary burn care center. IRA-Int J App Sci. 2016; 4(1):7-18

2. Gopalakrishnan R, Shivakami T, Sugapradha GR, et al. Prevalence and patterns of cracker blast injuries of the hand. Int Surg J. 2016; 3(2):831-6

3. Hatamabadi HR, Tabatabaey A, Heidari K, Khoramian MK. Firecracker injuries during Chaharshanbeh Soori festival inIran: A case series study. Arch Trauma Res. 2013;2(1):46-9.

4. Witsaman RJ, Comstock RD, Smith GA. Pediatric fireworks related injuries in the United States. Pediatrics. 2006;118(1):296303.

5. Mamoon R. Blast injuries of the hand. In: Cheema T, editors. Complex Injuries of the Hand. London: JP Medicals Ltd; 2014. p. 183-95.

6. Cernak I. Understanding blast-induced neurotrauma: how far have we come? Concussion. 2017;2(3):1-19

7. Champion HR, Holcomb JB, Young LA. Injuries from explosions: Physics, biophysics, pathology, and required research focus. J Trauma. 2009;66(5):1468-77.

8. Plurad DS. Blast injury. Mil Med. 2011; 176:276-82.

9. Freeland AE, Lineaweaver WC, Lindley SG. Fracture fixation in the mutilated hand. Hand Clin. 2003;19(1):51-61.

10. Logan SE, Bunkis J, Walton RL. Optimum management of hand blast injuries. Int Surg. 1990;75:109-14.

11. Berger LR, Kalishman S, Rivara FP. Injuries from fireworks. Pediatrics. 1985;75:877-82.

12. Adhikari S, Bandyopadhyay T, Sarkar T, Saha JK. Blast injuries to the hand: pathomechanics, patterns and treatment. J Emerg Trauma Shock. 2013;6(1):29-36.

13. Hazani R, Buntic RF, Brooks D. Patterns in blast injuries to the hand. Hand. 2009; $4(1): 44-9$.

14. Gelbart BR, Ukunda UNF, Muller J, Stuart W. 
Evaluation of firework injuries to the handNew Year 2007. SA orthop J. 2007;7(1):1826.

15. Campbell DA, Kay SR. The hand injury severity scoring system. J Hand Surg British Eur. 1995;21:295-8.
16. Urso-Baiarda F, Lyons RA, Laing JH, Brophy S, Wareham K, Camp D. A Prospectiove evaluation of the modified hand injury severity score in predicting return to work. Int J Surg. 2008;6(1):45-50. 